\title{
Regrowth and ornamental traits of bermudagrass fertilized with sewage sludge
}

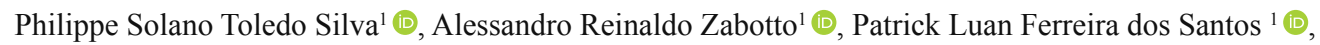

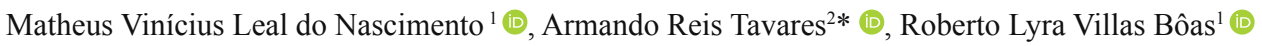 \\ ${ }^{1}$ Universidade Estadual Paulista (UNESP), Faculdade de Ciências Agronômicas, Botucatu-SP, Brazil. \\ ${ }^{2}$ Instituto Agronômico (IAC), Centro de Frutas, Jundiaí-SP, Brazil.
}

\begin{abstract}
The sewage sludge is a low-cost material and sustainable alternative to substitute chemical fertilizers on ornamental lawns and gardens. Thus, the objective was to evaluate the effects of the application of sewage sludge on the regrowth and ornamental traits of Discovery ${ }^{\mathrm{TM}}$ bermudagrass. The experiment was carried out during the fall/winter of 2019 . The turf was removed and left the soil exposed for a new grass regrowth. The treatments applied were $0,357,714,1,071$ and $1,428 \mathrm{~g} \mathrm{~m}^{-2}$ sewage sludge spread evenly on the lawn in a single dose. The evaluations were carried out after 120 days and the soil solution ( $\mathrm{EC}$ and $\left.\mathrm{NO}_{3}^{-}\right)$, $\mathrm{Normalized}^{-}$ difference vegetation index, root length, root + rhizome + stolon + leaves volume and digital image analysis were evaluated. The results showed that the increase of sewage sludge positively influenced the turfgrass development, both in the aesthetic aspect and on bermudagrass regrowth. The soil solution can show that the sludge increased the electrical conductivity and NO3-ions; however, it did not hinder the development of the lawn, even having positive correlations between these variables and the biometric evaluations of the plant. It is concluded that the dose of $1,428 \mathrm{~g} \mathrm{~m}^{-2}$ presented the best results for the evaluated characteristics, being the recommended one for use in the fertilization of bermudagrass Discovery ${ }^{\mathrm{TM}}$.
\end{abstract}

Keywords: biosolid, organic fertilization, ornamental turfgrass, sod production.

\section{Resumo}

\section{Características ornamentais e de rebrota da grama bermuda fertilizada com lodo de esgoto}

O lodo de esgoto é um material de baixo custo e alternativa sustentável para substituir fertilizantes químicos em gramados e jardins ornamentais. Assim, o objetivo do trabalho foi avaliar os efeitos da aplicação de lodo de esgoto nas características estéticas e na rebrota da grama bermuda Discovery ${ }^{\mathrm{TM}}$. O experimento foi realizado durante o outono/inverno de 2019, onde o gramado foi retirado com uma colhedora própria e deixado o solo exposto para uma nova rebrota da grama, e assim foram aplicados 0 ; 357 ; 714; 1071 e $1.428 \mathrm{~g} \mathrm{~m}^{-2}$ de lodo de esgoto espalhados uniformemente no gramado em dose única. As avaliações foram realizadas após 120 dias, sendo: solução do solo $\left(\mathrm{CE} \mathrm{e} \mathrm{NO}_{3}^{-}\right)$, Índice de vegetação por diferença normalizada, comprimento de raiz, volume de raiz+rizoma+estolão+folhas e análise por imagem digital. Os resultados demonstraram que o aumento das doses de lodo influenciou positivamente o desenvolvimento do gramado, tanto no aspecto estético quanto nas avaliações de rebrota do tapete. A solução do solo pôde evidenciar que o lodo aumentou a condutividade elétrica e íons de $\mathrm{NO}_{3}^{-}$, contudo não prejudicou o desenvolvimento do gramado, havendo inclusive correlações positivas entre essas variáveis e as avaliações biométricas da planta. Conclui-se que a dose de $1.428 \mathrm{~g} \mathrm{~m}^{-2}$ de lodo de esgoto apresentou os melhores resultados para as características avaliadas, sendo a dose recomendada para uso na grama bermuda Discovery ${ }^{\mathrm{TM}}$.

Palavras-chave: biossólido, fertilizante orgânico, gramado ornamental, produção de grama.

\section{Introduction}

There has been an accelerated growth of urban centers in Brazil, which has not been accompanied by the basic sanitation; thus, many of these sites do not have an adequate treatment of the waste generated (Castro et al., 2015). However, the creation of the National Solid Waste Policy (NSWP) Law $n^{\circ} 12,305$ of 2010, demands from the Brazilian Government the construction of Sewage Treatment Plants (STP) (Brasil, 2010). At the end of the

*Corresponding author: atavares2005@yahoo.com.br 
sewage treatment process (separation of the solid from the liquid residue), pollutants, nutrients and contaminants are concentrated in a single mass, called sewage sludge (Pedrosa et al., 2017). Usually, the sewage sludge produced is destined for landfills, generating a huge environmental impact. Consequently, there is a search for alternatives for sewage sludge final disposal, such as it uses in agriculture, which is regulated by the National Environment Council (CONAMA, 2006). The decree $\mathrm{n}^{\circ} 375$, define the treatment of sewage sludge before its use in agriculture as an organic fertilizer (Martins et al., 2018), due to the presence of pathogenic agents.

Sewage sludge is a material rich in nutrients and organic matter (Zhang et al., 2015; Li et al., 2017) mainly nitrogen $(\mathrm{N})$, the most responsive element in plants (Wang et al., 2019). The presence of organic matter in the residue has a direct influence on physical and biological properties of soils, increasing soil porosity and facilitating water drainage and, avoiding surface runoff (Silva et al., 2018). Several studies have demonstrated the potential of sewage sludge as a fertilizer (Lira et al., 2008; Nobile et al., 2014; Backes et al., 2017; Mota et al., 2019).

The $\mathrm{N}$ is the main nutrient involved in the quality, growth and aesthetics of lawns (Lusk et al., 2018). Nitrogen is an important component of molecules involved in chlorophyll synthesis (Santos and Castilho, 2018; Wu et al., 2019), granting an intense green color in lawns, greater density (closed and flawless lawns), reducing the recovery time to mechanical injuries, mainly caused by trampling (Gazola et al., 2016; Santos et al., 2019). Thus, the use of sewage sludge as a source of $\mathrm{N}$, can be a promising alternative to substitute mineral fertilizer (Mota et al., 2019) and to mitigate the impact of sewage sludge production. However, studies on the use of sewage sludge in turfgrass is restricted to emerald turfgrass (Zoysia japonica) (Backes et al., 2017; Mota et al., 2019), and bermudagrass (Cynodon spp.) (Nobile et al., 2014).

Discovery $^{\mathrm{TM}}$ is the new variety of bermudagrass (Cynodondactylon)(Khanal etal.,2017), recently introduced in Brazil, with some specific characteristics, differing from other species of the genus. Its color is composed of a bluish green, being extremely attractive and ornamental, it has a slow vertical growth rate, with pruning requirements $75 \%$ lower than others conventional bermudagrass, reducing maintenance fees. It also has good drought tolerance, cold and shade resistance, making it recommended for residential gardens, parks and commercial areas (Emmons and Rossi, 2015; Qually Grama, 2020). Thus, the objective of the work was to evaluate the effects of the application of sewage sludge on the aesthetic characteristics and the regrowth of bermudagrass Discovery ${ }^{\mathrm{TM}}$.

\section{Material and Methods}

The study was carried out in an experimental area with a long-lasting planting of Discovery ${ }^{\mathrm{TM}}$ bermudagrass. The climate in the region is $\mathrm{Cfa}$ (humid subtropical climate with abundant and well-distributed rainfall throughout the year), according to the Koppen climate classification. During the experiment period (autumn/winter 2019), the average temperature was $18.9^{\circ} \mathrm{C}, 62.59 \%$ of relative humidity and $161 \mathrm{~mm}$ of accumulated precipitation.

The soil is characterized as a dystrophic red Latosol (EMBRAPA, 2013), with chemical analysis described on Table 1. According to the chemical analysis of the soil, there was no need for liming, because the $\mathrm{V} \%$ was within the recommended range for sod production (Godoy et al., 2012), since the area had been installed for 1.5 years.

Table 1. Chemical analysis of soil in the experimental area.

\begin{tabular}{|c|c|c|c|c|c|c|c|c|c|}
\hline pH & O.M. & $\mathbf{P}_{\text {resine }}$ & $\mathbf{H}+\mathbf{A l}$ & $\mathbf{K}$ & $\mathrm{Ca}$ & Mg & BS & CEC & V\% \\
\hline $\mathrm{CaCl}_{2}$ & $g \mathrm{dm}^{-3}$ & $\mathrm{mg} \mathrm{dm}{ }^{3}$ & \multicolumn{7}{|c|}{ 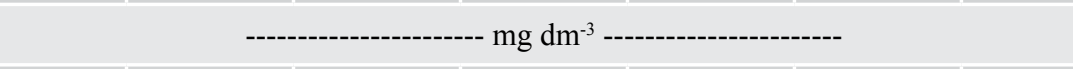 } \\
\hline 5.0 & 30 & 37 & 35 & 7.4 & 44 & 11 & 63 & 98 & 64 \\
\hline
\end{tabular}

CEC - cation exchange capacity, BS - sum of bases, V\% - base saturation percentage, O.M. - organic matter.

The sewage sludge used (Table 2) was obtained from SABESP STS (Sewage Treatment Station), located in Botucatu city, São Paulo State, Brazil. The waste went through the disinfestation process in the Art. 3 of
CONAMA Resolution $\mathrm{n}^{\circ}$ 375/2006 (CONAMA, 2006), remaining in drying bays for approximately 45 days, producing high temperatures (above $55{ }^{\circ} \mathrm{C}$ ), which let material dry (21\% humidity). 
Table 2. Chemical analysis of sewage sludge.

\begin{tabular}{|c|c|c|c|c|c|c|c|c|}
\hline $\mathbf{N}$ & $\mathbf{P}_{2} \mathbf{O}_{5}$ & $\mathbf{K}_{2} \mathbf{O}$ & $\mathbf{C a}$ & Mg & $\mathbf{S}$ & Moist. & O.M. & O.C. \\
\hline \multicolumn{8}{|c|}{-------------------- \% (natura) ---------------- } & dry \\
\hline 2.8 & 3.5 & 0.1 & 1.5 & 0.4 & 0.4 & 21 & 37 & 26 \\
\hline $\mathbf{N a}$ & B & $\mathbf{C u}$ & $\mathbf{F e}$ & Mn & $\mathbf{Z n}$ & $\mathbf{C} / \mathbf{N}$ & \multicolumn{2}{|c|}{ pH } \\
\hline \multicolumn{6}{|c|}{--- $\mathrm{mg} \mathrm{kg}^{-1}$ (natura) ---- } & & \multicolumn{2}{|c|}{ natura } \\
\hline 1,132 & 145 & 185 & 33,793 & 259 & 701 & $7 / 1$ & \multicolumn{2}{|c|}{5.8} \\
\hline
\end{tabular}

Moist. - moisture, O.M. - organic matter, O.C. - Organic carbon.

To carry out the experiment, $5 \mathrm{~cm}$ lawn were removed with a lawn harvester (Classen Hydro-Drive Sod Cutter, SCHV-18/5.5-motor Honda), leaving the soil exposed for new regrowth and lawn growth. After 30 days, the experimental plots of $1.5 \mathrm{~m}^{2}(1 \times 1.5 \mathrm{~m})$ with a $0.5 \mathrm{~m}$ border were delimited, totaling 15 units, and treatments were applied. The treatments were composed of $0 ; 357 ; 714$; 1,071 and $1,428 \mathrm{~g} \mathrm{~m}^{-2}$ sewage sludge corresponding to 0 , $10,20,30$ and $40 \mathrm{~g} \mathrm{~m}^{-2} \mathrm{~N}$ (Backes et al., 2017), respectively. The doses were spread equally over each experimental plot.

After 120 days of experimentation the following evaluations were performed: a) Ion monitoring of soil solution; b) Normalized difference vegetation index (NDVI); c) Root length and dry biomass volume; and, d) Digital image analysis.

The ion monitoring was performed using $30 \mathrm{~cm}$ soil solution extractors, which are composed of tubes with a ceramic end (acts as a filter) in contact with the soil, allowing the access of samples of the aqueous solution of the soil to a pre-established depth, and at the other end, there are two syringes to collect the solution. The extractors were installed $10 \mathrm{~cm}$ deep in the soil and a vacuum was applied to remove the air from inside of the extractor, $24 \mathrm{~h}$ before the material was collected. The solution was extracted with a syringe and submitted to electrical conductivity (EC) analyzes and $\mathrm{NO}_{3}^{-}$ analyses with quick reading kits. According to the adapted methodology of Gomes et al. (2019).

For NDVI, the portable GreenSeeker device was used to diagnostic plant vigor. The equipment emits brief bursts of red and infrared light, which intensity is detected by the equipment and is an indicator of the plant vigor. The sensor displays the values in NDVI that can range from 0.00 to 0.99 , measuring the vigor and density of the plants. For root length and dry biomass volume, samples of rhizomes, stolon and leaves from the turfgrass of each experimental plot were collected. The material was washed to remove the adhered soil. The root length was measured, and all samples were dried in an oven at $60{ }^{\circ} \mathrm{C}$, until constant weight for dry biomass.

The digital image analysis was performed with a $12 \mathrm{Mp}$ camera, with the support of a structure called "light box", similar to that produced by Peterson et al. (2011). The structure is a completely sealed box with lamps connected to a battery, in order to standardize the brightness and the photographed area. The images were transferred to a computer, and the RGB value (Blue, Green and Red) of each image was verified by the Adobe Fireworks ${ }^{\circledR}$ program. As only the green $(\mathrm{G})$ component does not define the green color, depending also on the red $(\mathrm{R})$ and blue (B) components, the RGB results were converted to HSB values (Hue, saturation and brightness), and the Dark Green Color Index (DGCI) was calculated, which varies from 0-1 (Karcher and Richardson, 2003), with the values of G, Hue and DGCI being presented.

The experiment was carried out in randomized 3 blocks with 5 sewage sludge doses. The results were subjected to analysis of variance (ANOVA) and Tukeyss test at the level of 5\% probability. Results showed an upward straight tendency and in the absence of the maximum point, for that reason regressions were not considered for analysis. Data analysis was performed by the Statistix 10 program.

\section{Results and Discussion}

The $\mathrm{N}\left(\mathrm{NO}_{3}^{-}\right)$analysis of the soil solution (Figure 1) showed that as the sewage sludge doses increased, the nitrate content in the soil augmented. The higher nitrate contents in soil (40 $\left.\mathrm{g} \mathrm{m}^{-2} \mathrm{~N}, p \leq 0.05\right)$ was observed on treatment with the highest sewage sludge dose $(1.428 \mathrm{~g}$ $\mathrm{m}^{-2}$ ). Due to the importance of $\mathrm{N}$ fertilization for the crop, the result demonstrates the potential of sewage sludge to supply $\mathrm{N}$ on turfgrass maintenance, with positive responses for plant dry biomass (Figure $2 \mathrm{C}$ ). The availability of $\mathrm{N}$ in soil solution is due to the nutritional composition of the residue, in our study sewage sludge had $2.8 \% \mathrm{~N}$, percentage higher than many organic residues used in agriculture such as charcoal (obtained from pyrolysis of eucalyptus), pinebark, cattle manure, coconut fiber, eucalyptus sawdust or vermiculite (Higashikawa et al., 2010). The utilization sewage sludge as a fertilizer also enhances organic matter to soils, contributing to the greater availability of $\mathrm{N}$. However, when organic materials are used as fertilizer, the availability of $\mathrm{N}$ for plants depends on of organic matter mineralization (Sempiterno et al., 2017). 

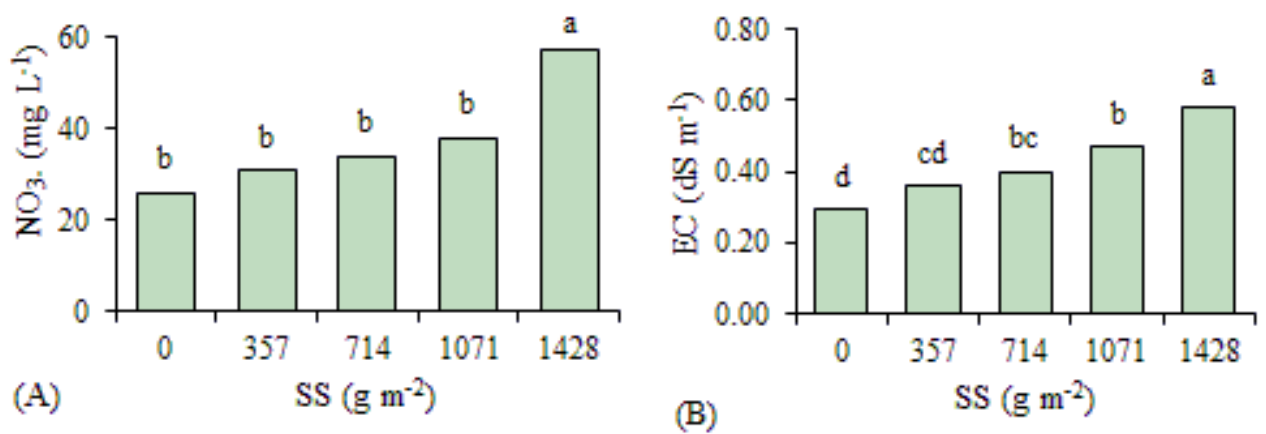

Figure 1. Nitrogen in soil solution (A) and electric conductivity (EC) (B) of Discovery ${ }^{\mathrm{TM}}$ bermudagrass on sewage sludge (SS) treatments.

The same patterns were observed for electrical conductivity of the soil solution (EC), which increased as the sewage sludge doses augmented. The highest sewage sludge dose $\left(1,428 \mathrm{~g} \mathrm{~m}^{-2}\right)$ resulted in a higher EC $(0.58$ $\left.\mathrm{dS} \mathrm{m}^{-1}\right)$. The high nutrients and organic matter contents inserted in the soil by the sewage sludge contributed to the increase of EC in soil solution, which is related to the higher occurrence of ions (Menezes and Matos, 2018). The increase of EC in soil solution indicates the higher greater presence of ions in the soil (Schlotter et al., 2012), and this technique is very accurate to estimate ions contents in soil (Gomes et al., 2019). Organic waste affects soil fertility properties; consequently, other parameters as soil acidity buffering capacity and the waste liming and agronomic value must be considered than only nutrient composition for sewage sludge use in agriculture (Carmo et al., 2016).

The highest dose of sewage sludge $\left(1,428 \mathrm{~g} \mathrm{~m}^{-2}\right)$ positively influenced the Normalized Difference Vegetation Index (NDVI), with an average of 0.53 (Figure 2A), 39.41\% higher compared to control treatment $\left(0 \mathrm{~g} \mathrm{~m}^{-2}\right)$. This index can indicate when the lawn is exposed to stresses such as trampling/compaction, utilization, and water deficit (Kerr et al., 2019; Straw et al., 2020). NDVI can be used as an alternative to evaluate the DCGI in the turfgrass (Caturegli et al., 2020). Higher NDVI indexes can be obtained according to the increase in turfgrass cover, density, and above-ground biomass, which may vary between grass species (Bremer et al., 2011).
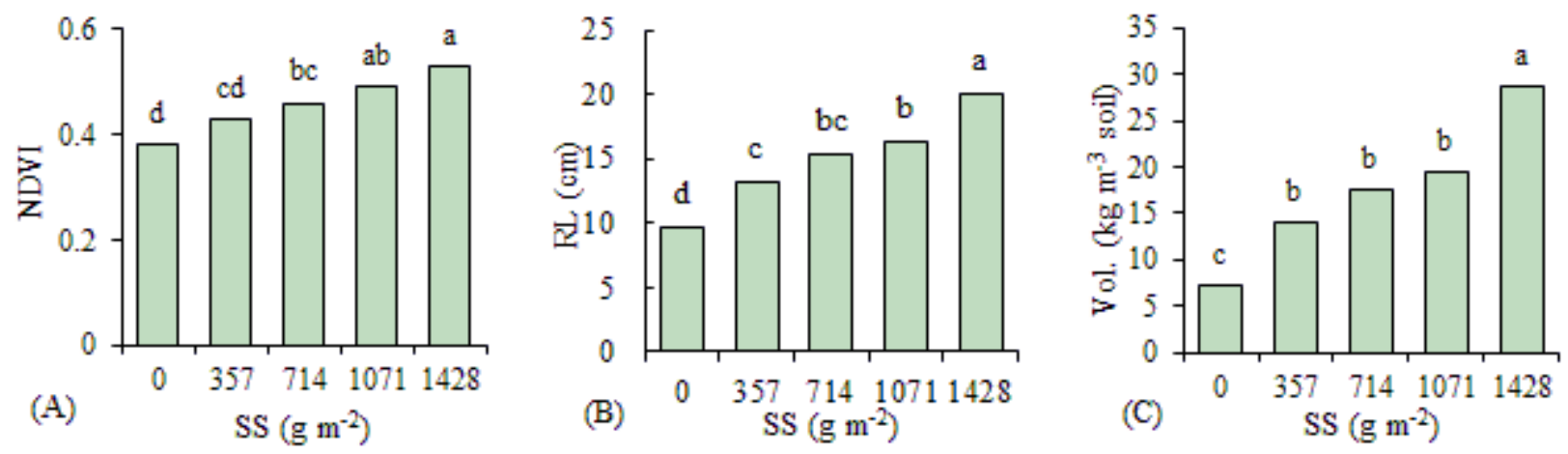

Figure 2. Normalized difference vegetation index (NDVI) (A), Root length (B) and Root + Rhizome + Stolon + Leaves volume (C) of Discovery ${ }^{\mathrm{TM}}$ bermudagrass on sewage sludge (SS) treatments

The root length (RL) was superior in treatment $1,428 \mathrm{~g}$ $\mathrm{m}^{-2}$ sewage sludge (Figure $2 \mathrm{~B}$ ), with $20 \mathrm{~cm}$. This variable is extremely important for the establishment and regrowth of the lawns, once higher RL values result in great uptake of nutrients and water, and consequently the formation of lawns in a lesser amount of time. The Root + Rhizome + Stolon + Leaves volume (Figure $2 \mathrm{C}$ ) reached the highest value $\left(28.67 \mathrm{~kg} \mathrm{~m}^{-3}\right)$ with the application of $1,428 \mathrm{~g} \mathrm{~m}^{-2}$ sewage sludge, value $291.67 \%$ higher than the control treatment. These data show the importance of adequate nutrition when soil still exposed, due to the lower regrowth observed in the area of control treatment $\left(0 \mathrm{~g} \mathrm{~m}^{-2}\right)$. Higher production of Root + Rhizome + Stolon + Leaves dry mass of emerald grass was also obtained with high doses of sewage sludge (30 Mg sewage sludge ha-1, equivalent to $300 \mathrm{~kg} \mathrm{ha}^{1}$ of $\mathrm{N}$ ), and similar to the area that received mineral fertilization (Backes et al., 2017). Backes et al. (2010) observed that high doses of sewage sludge, 
produced an excessive growth of the shoots in relation to root system. However, Lima et al. (2018) highlights the importance of the superior growth of roots, rhizomes and stolons compared to the shoots, once the formation and resistance of the lawn depends exclusively on these organs. The lower growth of the root system related to high doses of sewage sludge has already been observed in other plant species, as reported by Zabotto et al. (2020) and Gonçalves et al. (2015).

The parameter green component $(\mathrm{G})$ of the RGB color system do not show statistical difference with the application of sewage sludge (Figure 3A).
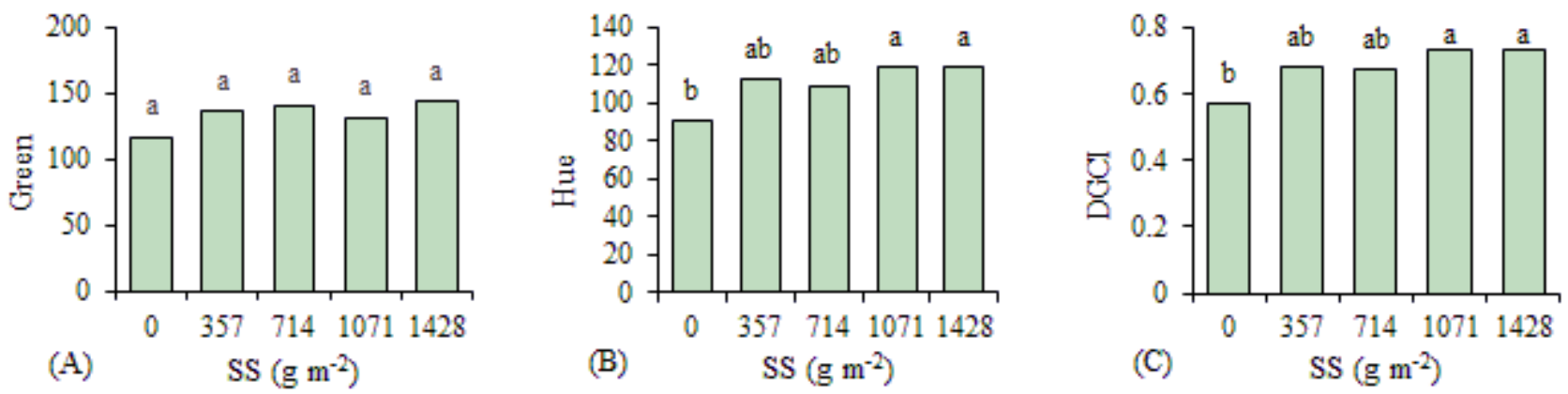

Figure 3. Green component (G) of the RGB color system (A), Hue (B) and Dark Green Color Index (DGCI) (C) of Discovery ${ }^{\mathrm{TM}}$ bermudagrass on sewage sludge (SS) treatments.

The $\mathrm{G}$ do not showed to be an accurate technique to estimate the color of the lawn, dependent of the blue and red values, as observed by Backes et al. (2010) and Gazola et al. (2016) in color evaluation of emerald grass. However, for the parameters hue and Dark Green Color Index (DGCI) (Figures 3B and C), the doses 1,071 and 1,428 $\mathrm{g} \mathrm{m}^{-2}$ sewage sludge were statistically higher than the other treatments. High doses of $\mathrm{N}$ in lawns promote a more intense green color (Godoy et al., 2012; Gazola et al., 2016) due to the increase of leaf chlorophyll (Santos et al., 2019). The hue of the lawn describes the pigment of a color at angles ranging from 0 to $360^{\circ}$, and for lawns, the values are generally between 60 to $120^{\circ}$, where the closer to $120^{\circ}$ the more intense the green color is (Godoy et al., 2012), with the highest doses of sewage sludge $\left(1,071\right.$ and $\left.1,428 \mathrm{~g} \mathrm{~m}^{-2}\right)$, with values of $119^{\circ}$. The present study showed that all treatments with sewage sludge results in superior hue $\left(103^{\circ}\right)$ and DGCI (0.63) values to those recommended for bermudagrass (Godoy et al., 2012). Higher DGCI values reflect darker green on the turfgrass, making it a desirable attribute for ornamental lawns (Gazola et al., 2016) as seen in Figure 4. The control treatment had the lowest value, showing that the application sludge influences this parameter. Lower index was also observed in Zeon grass (Zoysia matrella) due to low fertilization (Kamimura et al., 2020), demonstrating that the nutritional management may result in distinct DGCI.

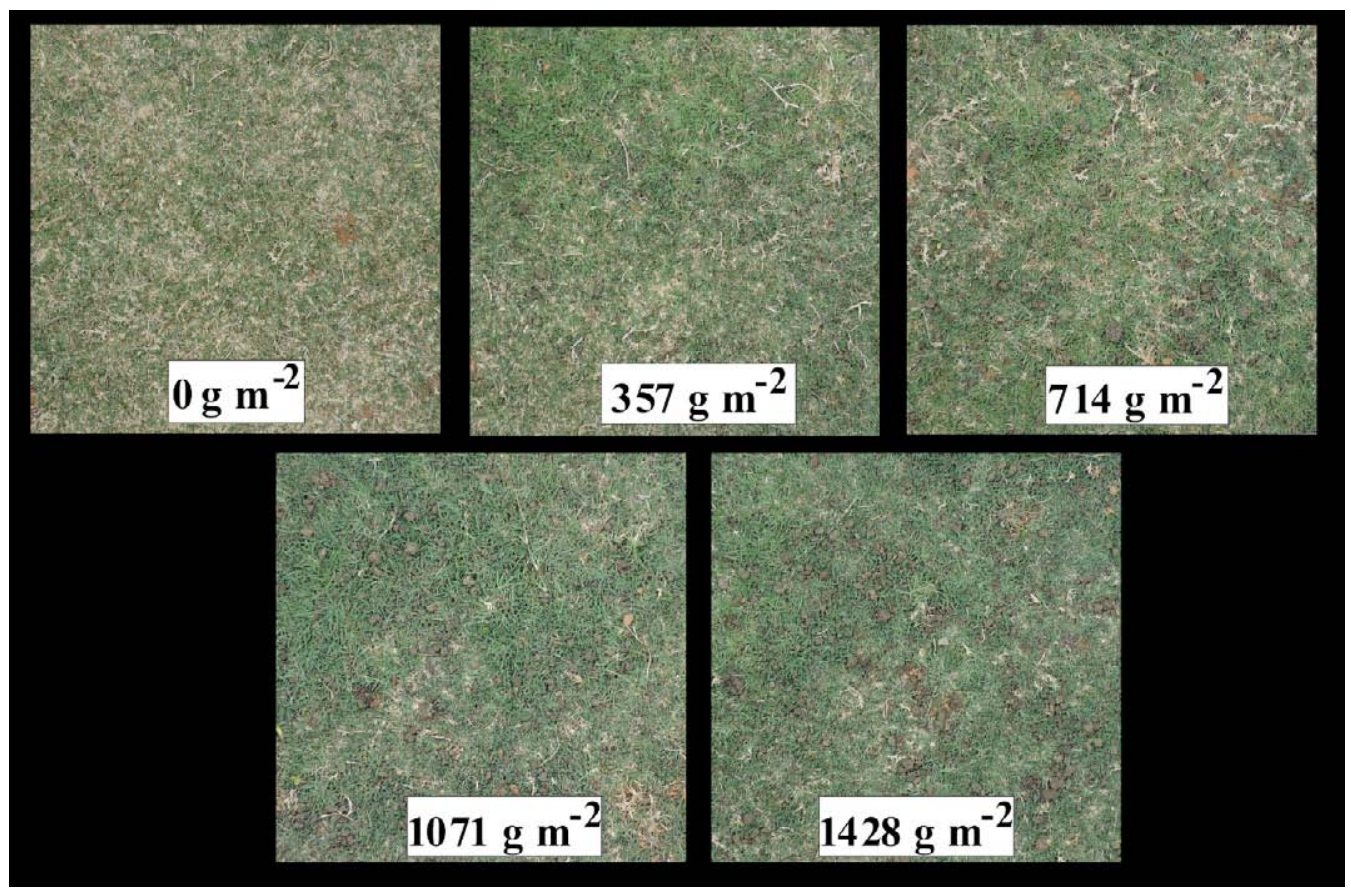

Figure 4. Digital images of Discovery ${ }^{\mathrm{TM}}$ bermudagrass on sewage sludge treatments. 
Pearson's correlation analysis showed a significant interaction between the $\mathrm{N}$ of the soil solution, volume of Root + Rhizome + Stolon + Leaves $(p \leq 0.01)$ and DGCI $(p \leq 0.05)$ (Table 3$)$. The correlation shows the linearity between two quantitative variables, that is, the association between them (Figueredo Filho and Silva Junior, 2009). Thus, the data demonstrate the importance of $\mathrm{N}$ for the initial development of the crop, contributing to greater growth and production of lawn biomass. Also, the correlation between $\mathrm{NO}_{3}^{-}$and the DGCI is associated with an increase in chlorophyll content, reflecting the intense green in lawns, and higher $\mathrm{NO}_{3}^{-}$concentration more intense is grass color (Oliveira et al., 2018; Santos et al., 2019). Chlorophylls are magnesian porphyrins composed of a central $\mathrm{Mg}$ atom, linked to another four of N (Santos and Castilho, 2018; Taiz and Zeiger, 2017). The correlation between nitrogen and green color index was also evidenced in emerald grass in work by Santos and Castilho (2015) and in bermudagrass 'Tifway 419' (Santos et al., 2019).

Table 3. Pearson's correlation coefficient.

\begin{tabular}{|c|c|c|c|c|c|c|c|}
\hline Treatments & $\mathrm{NO}_{3-}$ & Volume & DGCI & NDVI & RL & $\mathbf{G}$ & Hue \\
\hline Volume & $0.9264 * *$ & & & & & & \\
\hline DGCI & $0.5445^{*}$ & $0.6434^{*}$ & & & & & \\
\hline NDVI & $0.8583^{* *}$ & $0.9313^{* *}$ & $0.7561 * *$ & & & & \\
\hline CRN & $0.8883^{* *}$ & $0.9857 * *$ & $0.7126^{* *}$ & $0.959 * *$ & & & \\
\hline G & $0.4292^{\mathrm{ns}}$ & $0.5475^{*}$ & $0.236^{\mathrm{ns}}$ & $0.448^{\mathrm{ns}}$ & $0.5148^{*}$ & & \\
\hline Hue & $0.5679 *$ & $0.6654 * *$ & $0.9761 * *$ & $0.7778 * *$ & $0.7275^{* *}$ & $0.4048^{\mathrm{ns}}$ & \\
\hline $\mathbf{C E}$ & $0.9534 * *$ & $0.9663 * *$ & $0.6856^{* *}$ & $0.9567 * *$ & $0.9607 * *$ & $0.4252^{\mathrm{ns}}$ & $0.6965 * *$ \\
\hline
\end{tabular}

* - significant 5\%; ** - significant 1\%; ns - No significant. DGCI - Dark Green Color Index, NVDI - Normalized Difference Vegetation Index, RL Root Length, G - Green.

One of the positive factors for the use of sewage sludge in the nutritional management of lawns is the fact that the release of $\mathrm{N}$ occurs slowly, due to the mineralization of organic matter. In this way, the possibility of cost reduction in lawn maintenance, once $\mathrm{N}$ fertilization can be reduced or even eliminated, depending on the management adopted. Still, other macro and micronutrients are added to the soil, which are essential for plant development. Another important factor with the transformation of sewage sludge into fertilizer is the environmental contribution, significantly reducing the risks of pollution of the environment caused by incorrect waste disposal.

\section{Conclusions}

Our results demonstrate that sewage sludge has the potential to increase fertilizer in Discoverry ${ }^{\mathrm{TM}}$ bermudagrass. The application of sewage sludge positively influenced the availability of nitrate in the soil solution, the aesthetic traits, and the regrowth of the bermudagrass. It is recommended to use $1,428 \mathrm{~g} \mathrm{~m}^{-2}$ sewage sludge to fertilize Dicovery ${ }^{\mathrm{TM}}$ bermudagrass.

\section{Author Contribution}

P.S.T.S.: Field analysis, preparation and writing of the article, critical review. A.R.Z.: Field analysis, interpretation, preparation and writing of the article, critical review and translation. P.L.F.S.: Idea of the experiment, field analysis, data collection and analysis, interpretation, preparation and writing of the article and critical review. M.V.L.N.: Idea of the experiment, field analysis and data collection. A.R.T.: Critical review, translation and approval of the final version of the article. R.L.V.B.: Critical review, approval of the final version, work advisor.

\section{Acknowledgements}

The study was supported by São Paulo Research Foundation (FAPESP - Research Partnership for Technological Innovation - PITE, 13/50413-0).

\section{References}

BACKES, C.; LIMA, C.P.; GODOY, L.J.G., SANTOS, A.J.M., VILLAS BÔAS, R.L., BÜLL, L.T. Produção, acúmulo e exportação de nutrientes em grama esmeralda adubada com lodo de esgoto. Bragantia, v.69, p.413422, 2010. DOI: http://dx.doi.org/10.1590/S000687052010000200021

BACKES, C.; SANTOS, A.J.M.; GODOY, L.J.G.; VILLAS BÔAS, R.L.; RIBON, A.A.; BESSA, S.V. Efeito residual do lodo de esgoto e de manejos mecanizados na produção de tapetes e na extração de nutrientes pela grama esmeralda. Espacios, v.38, n.14, p. 3, 2017. 
BRASIL. Lei $\mathrm{n}^{\mathrm{o}} 12.305$, de 2 de agosto de 2010. Política Nacional de Resíduos Sólidos. Available at: <http://www. planalto.gov.br/ccivil_03/_ato2007-2010/2010/lei/112305. htm>. Accessed on: June 9, 2020.

BREMER, D.J.; LEE, H.; SU, K.; KEELEY, S.J. Relationships between normalized difference vegetation index and visual quality in cool-season turfgrass: II. Factors affecting NDVI and its component reflectance. Crop Science, v.51, n.5, p.2219, 2011. DOI: https://doi. org/10.2135/cropsci2010.12.0729

CARMO, D.L.D.; LIMA, L.B.D.; SILVA, C.A. Soil fertility and electrical conductivity affected by organic waste rates and nutrient inputs. Revista Brasileira de Ciência do Solo, v.40, 0:e0150152, 2016. https://doi.org/10.1590/ S0100-06832010000500026

CASTRO, A.L.F.G.; SILVA, O.R.; SCALIZE, P.S. Cenário da disposição do lodo de esgoto: uma revisão das publicações ocorridas no Brasil de 2004 a 2014. MultiScience Journal, v.2, n.1, p.66-73, 2015. DOI: http:// dx.doi.org/10.33837/msj.v1i2.84

CATUREGLI, L.; GAETANI, M.; VOLTERRANI, M.; MAGNI, S.; MINELLI, A.; BALDI, BRANDANI, G.; MANCINI, M.; LENZI, A.; ORLANDINI, S.; LULLI, F.; BERTOLDI, C.; DUBBINI, M.; GROSSI, N. Normalized difference vegetation index versus Dark Green Colour Index to estimate nitrogen status on bermudagrass hybrid and tall fescue. International Journal of Remote Sensing, v.41, n.2, p.455-470, 2020. DOI: https://doi.org/10.1080/0 1431161.2019.1641762

CONAMA. Resolução no 375, de 29 de agosto de 2006. Define critérios e procedimentos, para o uso agrícola de lodos de esgoto gerados em estações de tratamento de esgoto sanitário e seus produtos derivados, e dá outras providências. Available at: <http://www2.mma.gov.br/ port/conama/res/res06/res37506.pdf $>$ Accessed on: May 15 th 2020 .

EMBRAPA. Sistema Brasileiro de Classificação de Solos. 3ed. Brasilia: EMBRAPA, 2013. 353p.

EMMONS, R.; ROSSI, F. Turfgrass science and management. Independence: Cengage Learning, 2015. 608 .

FIGUEIREDO FILHO, D.B.; SILVA JÚNIOR, J.A. Desvendando os Mistérios do Coeficiente de Correlação de Pearson (r). Revista Política Hoje, v.18, n.1, 2009.
GAZOLA, R.P.D.; BUZETTI, S.; GAZOLA, R.N.; CASTILHO, R.M.M.; TEIXEIRA FILHO, M.C.M.; CELESTRINO, T.S.; DUPA, E. Nitrogen dose and type of herbicide used for growth regulation on the green coloration intensity of Emerald grass. Ciência Rural, v.46, n.6, p.984-990, 2016. DOI: http://dx.doi.org/10.1590/0103$8478 \mathrm{cr} 20150276$

GODOY, L.J.G.; VILLAS BÔAS, R.L.; BACKES, C.; SANTOS, A.J.M. Nutrição, adubação e calagem para produção de gramas. Botucatu: FEPAF, 2012. 146p.

GOMES, E.R.; BRESSAN, D.F.; COSCOLIN, R.B.S.; CAPELIN, D.; BROETTO, F. Uso de extrator de solução no monitoramento da fertilidade do solo no cultivo do feijoeiro. Revista AGROFIB, v.1, n.1, p., 2019.

GONÇALVES, J.L.M.; ALVARES, C.A.; SOUZA, A.H.B.N.; JUNIOR, J.C.A. Caracterização edafoclimática e manejo de solos das áreas com plantações de eucalipto. In: SCHUMACHER, M.V.; VIERA, M. (Org.). Silvicultura do eucalipto no Brasil. Santa Maria: Editora da Universidade Federal de Santa Maria, 2015. p.111-154.

HIGASHIKAWA, F.S.; SILVA, C.A.; BETTIOL, W. Chemical and physical properties of organic residues. Revista Brasileira de Ciência do Solo, v.34, n.5, p.1742$1752,2010$.

KAMIMURA, L.M.T.; GODOY, L.J.G.; BOAS, R.L.V. Fertirrigação e fertilizantes de liberação gradual para a implantação de gramado esportivo. Irriga, v.25, n.1, p.184-201, 2020. DOI: https://doi.org/10.15809/ irriga.2020v25n1p184-201

KARCHER, D.E.; RICHARDSON, M.D. Quantifying turfgrass color using digital image analysis. Crop Science, v.43, p.943-951, 2003. DOI: https://doi.org/10.2135/ cropsci2003.9430

KERR, R.A.; MCCARTY, L.B.; BROWN, P.J.; HARRIS, J.; MCELROY, J.S. Immediate irrigation improves turfgrass safety to postemergence herbicides. HortScience, v.54, n.2, p.353-356, 2019. DOI: https://doi.org/10.21273/ HORTSCI13571-18

KHANAL, S.; SCHWARTZ, B.M.; KIM, C.; ADHIKARI, J.; RAINVILLE, L.K.; AUCKLAND, S.A.; PETERSON, A.H. Cross-taxon application of sugarcane EST-SSR to genetic diversity analysis of bermudagrass (Cynodon spp.). Genetic Resources and Crop Evolution, v.64, p.20592070, 2017. DOI: https://doi.org/10.1007/s10722-0170496-2 
LI, S.; LI, D.; LI, J.; LI, G.; ZHANG, B. Evaluation of humic substances during co-composting of sewage sludge and corn stalk under different aeration rates. Bioresource Technology, v.245, p.1299-1302, 2017. DOI: http://dx.doi. org/10.1016/j. biortech.2017.08.177

LIMA; C. P.; SANTOS, A. J. M.; VILLAS BÔAS, R. L.; FERNANDES, D. M.; GODOY, L. . G.; OLIVEIRA, M. R. Sod production and the effects of liquid organo-mineral fertilizers and thickness of sod. Scientia Agricola, v.75, n.4, p.346-353, 2018. DOI: https://doi.org/10.1590/1678992x-2016-0320

LIRA, A.C.S.D.; GUEDES, M.C.; SCHALCH, V. Reciclagem de lodo de esgoto em plantação de eucalipto: carbono e nitrogênio. Engenharia Sanitária e Ambiental, v.13, n.2, p.207-216, 2008. DOI: https://doi.org/10.1590/ S1413-41522008000200011

LUSK, M.G.; TOOR, G.S.; INGLETT, P.W. Characterization of dissolved organic nitrogen in leachate from a newly established and fertilized turfgrass. Water Research. v.131, n.15, p.52-61, 2018. DOI: https://doi. org/10.1016/j.watres.2017.11.040

MARTINS, C.A.C., SANTOS, F.S., PORTZ, A., SANTOS, A.M. Desenvolvimento inicial do milho (Zea mays L.) em substrato contendo lodo de esgoto compostado. Revista Brasileira de Ciências Ambientais, v.48, p.69-79, 2018. DOI: http://dx.doi.org/10.5327/Z2176-947820180305.

MENEZES, L.A.N.; MATOS, A.T. Condutividade elétrica do solo em função da dose de aplicação de água residuária em áreas de fertirrigação. Revista Engenharia na Agricultura, v.26, n.4, p.383-389, 2018. DOI: https://doi. org/10.13083/reveng.v26i4.956

MOTA, F.D.; VILLAS BÔAS, R.L.; MATEUS, C.M.D.; SILVA, T.B.G. Sewage sludge compost in zoysia grass sod production. Revista Ambiente \& Água, v.14, n.1, e2301, 2019. DOI: https://doi.org/10.4136/ambi-agua.2301

NOBILE, F.O.; NUNES, H.D.; NEVES, J.C. Doses de lodo de esgoto sobre o desenvolvimento da grama bermuda (Cynodon dactylon). Nucleus, v.11, n.2, 2014. DOI: http:// dx.doi.org/10.3738/1982.2278.1046

OLIVEIRA, N.B.; OLIVEIRA, J.F.V.; SANTOS, P.L.F.; GAZOLA, R.P.D.; CASTILHO, R.M.M. Avaliação do estado nutricional de três gramados ornamentais em Ilha Solteira-SP: um estudo de caso. Revista LABVERDE, v.9, n.1, p.96-119, 2018. DOI: http://dx.doi.org/10.11606/ issn.2179-2275.v9i1p96-119

PEDROSA, M.V.B., LIMA, W.L., AMARAL, A.A., CARVALHO, A.H.O. Biossólido de lodo de esgoto na agricultura: desafios e perspectivas. Revista Agroambiental, v.9, n.4, p.125-142, 2017. DOI: http:// dx.doi.org/10.18406/2316-1817v9n42017999
PETERSON, K.; SHONKWILER A., K.; BREMER, D. Custom light box for digital image turfgrass analysis. In: K-State Turfgrass Research. Kansas: K-State University Publications, 2011. p. 89-91. Available at: <https://krex.kstate.edu/dspace/bitstream/handle/2097/15414/SRP1053. pdf? sequence $=1 \&$ isAllowed $=y>$. Accessed on: March 21, 2020.

QUALLY GRAMA. Discovery ${ }^{\mathrm{TM}}$ Bermudagrass Less Mowing. 5p. Available at: <https://www.quallygrama. com.br/grama-discovery-lancamento.pdf $>$. Accessed on: January 20, 2020.

SANTOS, P.L.F.; CASTILHO, R.M.M. Relação entre teor de clorofila e nitrogênio foliar em grama esmeralda cultivada em substratos. Tecnologia \& Ciência Agropecuária, v.9, n.2, p.51-54, 2015.

SANTOS, P.L.F.; CASTILHO, R.M.M. Substrates in the development of a sports turfgrass "Tifton 419". Ornamental Horticulture, v.24, n.4, p.138-144, 2018. DOI: https://doi.org/10.14295/oh.v24i2.1155

SANTOS, P.L.F.; CASTILHO, R.M.M.; GAZOLA, R.P.D. Pigmentos fotossintéticos e sua correlação com nitrogênio e magnésio foliar em grama bermuda cultivada em substratos. Acta Iguazu, v.8, n.1, p.92-101, 2019.

SCHLOTTER, D.; SCHACK KIRCHNER, H.; HILDEBRAND, E.E.; VON WILPERT, K. Equivalence or complementarity of soil solution extraction methods. Journal of Plant Nutrition and Soil Science, v.175, n.2, p.236-244, 2012. DOI: https://doi.org/10.1002/jpln.201000399

SEMPITERNO, C.; FERNANDES, R.; PEIXOTO, L. Valorização agrícola de lamas de ETAR: disponibilidade de azoto. Revista de Ciências Agrárias, v.40, n.3, p.506-514, 2017. DOI: http://dx.doi.org/10.19084/RCA17081

SILVA, F.A.M.; NUNES, G.M.;ZANON, J.A.; GUERRINI, I.A.; SILVA, R.B. Resíduo agroindustrial e lodo de esgoto como substrato para a produção de mudas de Eucalyptus urograndis. Ciência Florestal, v.28, n.2, p.827-828, 2018. DOI: http://dx.doi.org/10.5902/1980509832101

STRAW, C. M.; GRUBBS, R. A.; HENRY, G. M. Short term spatiotemporal relationship between plant and soil properties on natural turfgrass sports fields. Agrosystems, Geosciences \& Environment, v.3, n.1, p.1-11, 2020. DOI: https://doi.org/10.1002/agg2.20043

TAIZ, L.; ZEIGER, E. Fisiologia e desenvolvimento vegetal. 6ed. Porto Alegre: Artmed, 2017. 858p.

WANG, P.; WANG, Z.; SUN, X.; MU, X.; CHEN, H.; CHEN, F.; YUAN, L.; MI, G. Interaction effect of nitrogen form and planting density on plant growth and nutrient uptake in maize seedlings. Journal of Integrative Agriculture, v.18, n.5, p.1120-1129, 2019. DOI: http:// dx.doi.org/10.1016/s2095-3119(18)61977-x 
WU, Y.W.; LI, Q.; JIN, R.; CHEN, W.; LIU, X.L.; KONG, F.L.; KE, Y.P.; SHI, C.; YUAN, J.C. Effect of low-nitrogen stress on photosynthesis and chlorophyll fluorescence characteristics of maize cultivars with different lownitrogen tolerances. Journal of Integrative Agriculture. v.18, n.6, p.1246-1256, 2019. DOI: https://doi.org/10.1016/ S2095-3119(18)62030-1

ZABOTTO, A.R.; GOMES, L.D.L.; MATEUS, C.D.M.; VILLAS BÔAS, R.L.; KANASHIRO, S.; TAVARES, A.R. Nutrition and physiology of hybrid Eucalyptus urograndis in soil fertilized with sewage sludge. Emirates Journal of Food and Agriculture, v.32, n.1, p.19-24, 2020. DOI https://doi.org/10.9755/ejfa.2020.v32.i1.2054
ZHANG, J.L.V.B.; XING, M.; YANG, J. Tracking the composition and transformation of humic and fulvic acids during vermicomposting of sewage sludge by elemental analysis and fluorescence excitation-emission matrix. Waste Manage, v.39, p.111-118, 2015. DOI: https://doi. org/10.1016/j.wasman.2015.02.010 